\title{
Bottom Fauna and the Food of Fishes.
}

\author{
By \\ G. A. Steven, B.Sc., \\ Assistant Naturalist at the Plymouth Laboratory.
}

With 1 Chart and 3 Figures in the Text.

In the waters off Plymouth there exists a definite inshore fishing-ground, approximately 13 square miles in area, locally known as the "corner." In order to obtain some idea of the Bionomic conditions prevailing on this ground an intensive study of the bottom fauna was undertaken. Quantitative seasonal observations extending over a period of one year (August, 1928-July, 1929 inclusive) have been made, 'using the $0 \cdot 1$ square metre Bottom Sampler and the "Agassiz" Trawl, a method having been devised for obtaining quantitative hauls with the latter instrument. Investigations into the food actually eaten by the fishes within the area have been carried on simultaneously, and the stomach contents of over 2000 fishes comprising 29 different species have been examined. On account of the length of time required for stomach examination, it was found impossible to make seasonal observations on them also, but comparable winter and summer examinations were made.

I am deeply indebted to Dr. Allen and the Staff of the Laboratory for much advice and other assistance throughout the course of this work. My very best thanks are also due to Capt. Lord and the crew of the s.s. Salpa for their invaluable co-operation and constant endeavour to reap the best results from all operations at sea.

\section{Methods of Collection.}

The quantitative faunistic observations were made in the first place by means of the Petersen $0 \cdot 1$ square metre bottom sampler (Petersen "grab"). Fifteen stations were fixed, more or less evenly distributed over the area -i.e. one station to rather less than one square mile (see Chart, p. 678). In autumn, 1928, and in winter, spring, and summer following, five bottom sampler hauls were taken at each of these stations.

Examination of the stomach contents of fishes from the same area soon disclosed the fact that a number of organisms-Pandalidæ, Crangonidæ, NEW SERIES.-VOL. XVI. No. 3. MAY, 1930. 
Palæmonidæ, Hippolytidæ-were being preyed upon which were not represented at all in grab samples. A species of Portunus-P. depuratoralso appeared frequently in stomach contents but not in grab hauls. An additional quantitative collecting method had therefore to be devised to supplement that of the bottom sampler. For this purpose the "Agassiz" trawl was eventually used in the following manner.

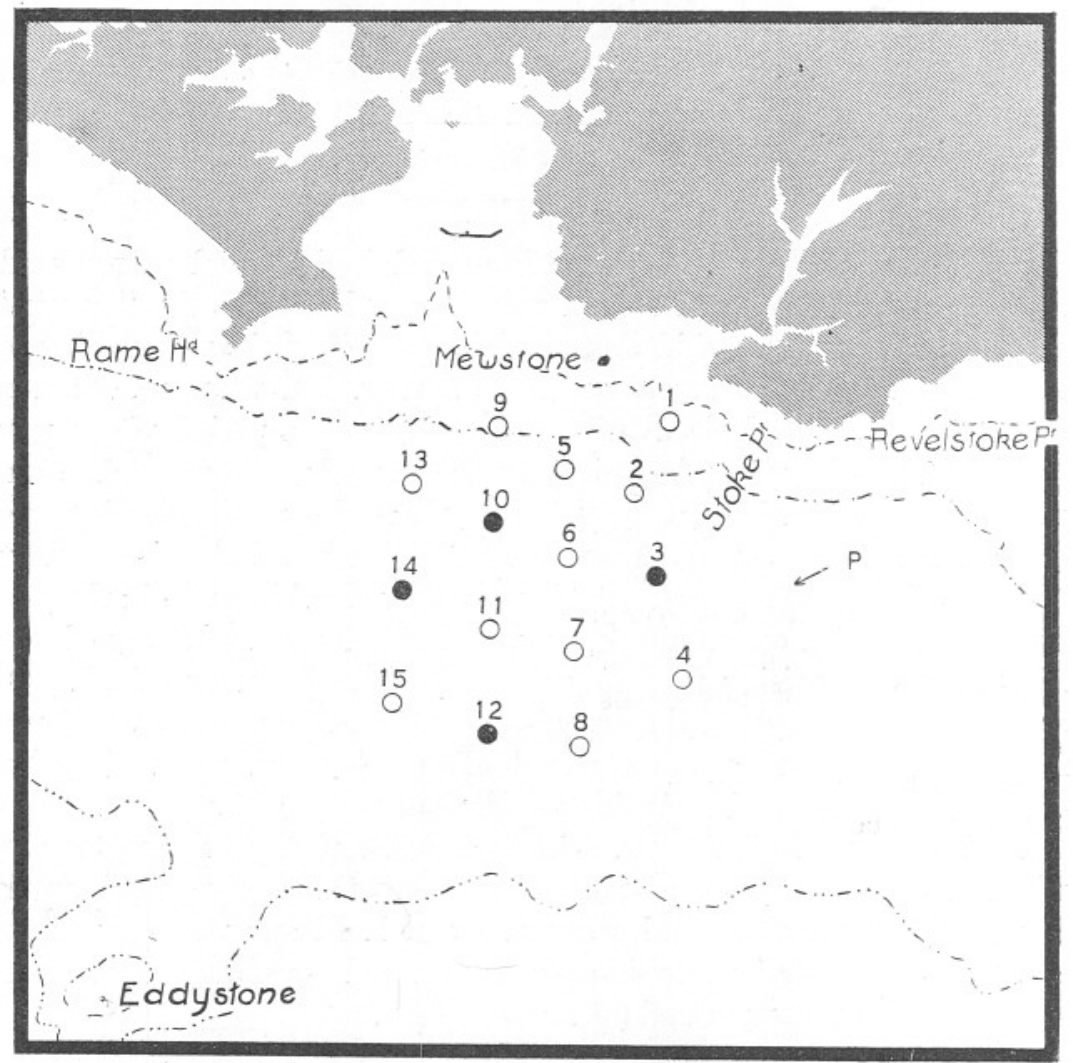

Chart of Bottom Sampler Stations and Trawl Centres on the "Corner "Fishing Ground off Plymouth, 1928-29.

$\mathbf{o}=$ Bottom Sampler Stations.

- = Bottom Sampler Stations also used as Trawl Centres.

Four representative grab stations-3, 10, 12, 14-were chosen as trawling centres. A trawler's "dan "was anchored on the station to be worked. The trawl was then shot so as to strike bottom as nearly as possible alongside the dan and towed in a straight line away from it for a distance of approximately 520 yards. Four hauls were taken around each trawl centre, towing in directions north, south, east, and west in turn from. 
the dan. The distance trawled was ascertained by using a range-finder* for observing the distance of the ship from the dan when the trawl was hauled clear of the bottom, due allowance being made for the length of warp paid out. The trawl used had a 7 -foot beam-i.e. the mouth was 7 foot wide. By towing it over a distance of 520 yards, therefore, an area of approximately $\frac{1}{4}$ acre was covered at each haul. Thus a total area of roughly one acre was represented by the four trawl samples taken around each trawl centre. Unfortunately the trawl and range-finder were not brought into operation while the first (autumn) series of grab samples was being taken, so that trawl records are available only for the winter, spring, and summer seasons (Table IV).

By the use of the range-finder and dan one at least of the objections put forward by Petersen (19, p. 47) against the use of the trawl for quantitative estimation of the animal life on the sea bottom is overcome. He says, "If we wish to have accurate information regarding the amount of animal life, especially the number of individuals per unit of surface, we must rely upon other apparatus than the dredge and trawl ; with these it is difficult to say what distance they have been dragged over the bottom, nor can we know how many animals they have left behind on the distance worked over: the number is often many times that taken up." The latter objection still holds. But even though it be impossible to estimate how many animals a trawl fails to capture, it is nevertheless permissible to hold the view that the animals it does bring up represent, at any rate, the minimum number of individuals present on the area covered. And this is all that can be claimed for the bottom sampler. It may and probably does bring up samples which represent fairly accurately the population of a sea bottom composed of soft mud or mire such as seems to be typical of much of the Limfjord (19, p. 14), for example. But on bottoms of a harder nature composed of sand or gravel, either with or without an admixture of mud, the performance of the bottom sampler is not so satisfactory. We can count the number of individuals it brings up, but have no way of knowing how many animals it leaves behind in their burrows beyond the reach of its "bite." Moreover, in such places as the Limfjord, active members of an epifauna, such as Portunus depurator which abounds on the " corner" grounds off Plymouth, appear to be present only in negligible numbers. Where such occur they too, more often than not, evade capture by the grab, probably scuttling out of its way as it descends upon them from above. Such species as Pandalina brevirostris, Palæmonidæ, and the Crangonidæ, important food animals in the " corner " area, do not come within its scope at all $: \uparrow$ the trawl, whatever its limitations, is the most effective instrument for their capture. In order, therefore, to

* The instrument used was a Barr and Stroud range-finder, type F.T. 32 . Base $80 \mathrm{~cm}$.

$\uparrow$ It is not designed to capture these animals. 
acquire more complete data regarding the food animals present upon the ground under investigation than was possible with the bottom sampler alone, both sampler and trawl have been used in conjunction, the former for bringing up the sedentary infauna and the latter for the more active animals roaming on or above the sea bottom.

\section{THE BOTTOM FAUNA.}

In Table III is recorded the number of individuals of separate species or homogeneous groups per 0.5 square metre at each station as brought up in 5 hauls of the $0 \cdot 1$ square metre bottom sampler. Columns a, b, c, d are the data for autumn, 1928, and the following winter, spring, and summer respectively. Table IV records the number of animals brought up by the "Agassiz" trawl from $\frac{1}{4}$ acre of bottom N., S., E., and W. of each of the four stations 3, 10, 12, and 14. Only three seasons' observations (b, c, d) are available as explained above.

Seasonal observations were taken in order to determine what fluctuations, if any, of density or distribution of the bottom invertebrates take place in the course of a year. It will be seen from the tables that on the whole, both number and distribution of most of the organisms remained fairly constant. Pandalina brevirostris and some Crangonids were the only species which showed very definite migratory movements (Table IV). During the winter months Pandalina was more or less evenly distributed over the whole of the " corner " ground in depths of from 25-28 fathoms, with a tendency to be most numerous near the south-western edge where the water is deepest. In spring, Pandalina had moved shorewards and congregated in an immense shoal along the outer edge of the rough ground between Stoke Pt. and Revelstoke Pt. (see chart). They had then all but disappeared from most of the " corner" area west of stations 3 and 4, but were very numerous at those points and south-eastwards of them. A $\frac{1}{4}$-acre "Agassiz" haul taken in the month of April, towing from the point $\mathrm{P}$ on the chart in the direction indicated by the arrow, contained 537 individuals.

This shoreward migration in the spring seems to be a spawning migration into shallower water. In March, ovigerous females carrying eggs of a very pale pink colour became numerous in the catches. As the eggs ripen their colour changes to pale green, when they are ready to be shed. "Green-bellied " females became numerous in May and remained plentiful until the end of July. The main spawning season, therefore, seems to extend over a period of about three months. A certain amount of spawning evidently goes on for a longer time for the larvæ were abundant in the plankton until September and a few were still to be found at the time of writing (October, 1929). 
Kemp (12) and Murie (17) describe a similar gregarious migratory habit in another Pandalid, Pandalus montagui. But in the case of this species the spawning migration is an off-shore one. Murie (p. 245) states that although nothing definite is known on this point, yet there is good reason for believing that around the long parallel sand-banks girding the outer arch facing Essex, the "pink shrimps" of the Thames estuary flock in the early spring to spawn. And the Humber shrimp trawlers "know quite well that the appearance of 'green-bellies' is a sign that the prawns will soon be off to sea" (12, p. 88 , footnote). It may be, then, that in estuarine regions such as those of the Thames and Humber, the large sand-banks and sand-flats at their mouths far off-shore, provide for $P$. montagui conditions suitable for spawning similar to those sought by Pandalina brevirostris in an in-shore migration from the deep and open sea.

Two species of the Amphipod genus Ampelisca-A. spinipes and A. tenuicornis - are present on the "corner" grounds. The former species is confined to bottoms of fairly clean sand or shell gravel-e.g. on and around Station 1. The latter with a preference for more muddy conditions is present over the whole area with the exception of Station 1. For convenience the two species are grouped together as Ampelisca spp. in Table III. From this table it will be seen that in autumn, 1928, these Amphipods were numerous on the western line of stations-13, 14, 15and were also distributed in small numbers over the remainder of the area. In the following winter, however, they had almost entirely disappeared from the grounds, as recorded by the bottom sampler. Several additional hauls taken outside the area, both to seaward and to landward, also revealed a scarcity of Ampelisca. At first it was thought that, on the approach of winter, a great diminution in their numbers had taken place, either by natural death or otherwise. But this explanation had to be abandoned when young Rays $(20-30 \mathrm{~cm}$.) captured on the "corner" grounds at this time were found to have been feeding largely, and in some cases exclusively, on Ampelisca (Table II, p. 695). It is evident, therefore, that the Amphipods were still abundantly available to the fishes on the ground although, for some reason, the grab failed to capture them. Unfavourable weather and bad working conditions when the winter hauls were taken, which may suggest itself as a possible explanation, does not apply. Winter stations 13,14 , and 15 were worked in much more favourable conditions of wind and sea than were encountered at stations 9,10 , 11, and 12, for example, in the spring series of observations when 42, 109, 35 , and 9 individuals respectively were taken off 0.5 square metres. Possibly Ampelisca may burrow deeply into the mud during the winter months, beyond the reach of the grab. In any case, whatever the explanation, the facts are interesting and important in so far as they serve to 
illustrate the danger of assuming that a species is absent from the grounds when it is not to be found in the bottom sampler hauls.*

Perusal of Tables III and IV serves to show the great (numerical) richness of the organisms comprising the infauna as compared with those of the epifauna, even allowing for any discrepancy there may be in the sampling efficiency of the grab and trawl. The numbers as a whole, in both tables, are roughly of the same order of magnitude. But, where they represent the population of 0.5 square metre in the case of the grab samples (Table III) they represent the population of $\frac{1}{4}$ acre $(=0.5 \mathrm{sq} . \mathrm{m} . \times 2023 \cdot 35)$ for trawl samples (Table IV). Of U pogebia deltaura, for example, a burrowing crustacean found all over the "corner" grounds, totals of 11, 5, 14, and 18 individuals were taken at all stations in autumn, winter, spring, and summer respectively. These numbers captured over an area of $15 \times 0.5$ square metres represent a calculated population of 1484, 674, 1888, 2428 individuals respectively per $\frac{1}{4}$ acre. For $U$. stellata the corresponding figures, as calculated, are $674,674,1349$, and 1484 respectively. These numbers are far in excess of those for any species of the epifauna.

From Table III it will further be seen that the two species of Upogebia, considered together, are fairly uniformly distributed over the whole area. Calculating further on this basis, the Upogebia spp. population of the "corner" grounds exceeded 72 millions, 45 millions, 108 millions, and 130 millions in the autumn, winter, spring, and summer seasons respectively. These values, large though they be, probably fall far short of the actual numbers present, as, owing to the burrowing habit of this animal and the agility with which it darts into and along its underground passages, the bottom sampler is not likely to capture more than a small fraction of the total number of individuals present in the area from which it "bites."

The two species of Upogebia, therefore, form in themselves alone a vast potential food supply on the "corner" grounds. Nevertheless, although present in far greater numbers than Portunus depurator, for example, it does not necessarily follow that they are actually more important as a source of fish food. Prey, to be of service to any animal, must first of all be caught and eaten.

On this point, Ford (\%, p. 532) remarks, "Before the potential value of a bed of Lamellibranchs as food for fishes can become known, the precise food value of the successive stages of the life-history of each lamellibranch must be determined. One species may never grow beyond a size which a medium-sized Dab could easily swallow whole, whereas another although it may be easily devoured in its early life will soon grow

* In this connexion, the relative inefficiency of every type of gear when compared with fishes as collectors, may be cited. In the waters off Plymouth, Sipunculus has never been taken in any collecting instrument. Nevertheless, this Gephyrean is commonly found in the stomachs of Rough Dogfishes (Scyliorhinus canicula) caught in these waters. 
to a size quite beyond the largest of shell-eating fish and thus be relatively useless to fishes. In quantitative estimations of fish food similar to those made by the Danish investigators, this fact needs careful consideration." With sedentary hard-shelled organisms such as Lamellibranchs, size is the main consideration. But the burrowing habit of Upogebia and the alacrity with which it can scurry to safety, make its relatively great elusiveness as compared with that of Portunus, for example, a significant factor which must be taken into consideration in any attempt to estimate their relative values as sources of fish food.

This factor-the comparative availability of the food animals present on or in the sea-floor - is one the importance of which impresses itself upon the investigator, but except in certain cases - e.g. effect of size-he remains powerless to grapple effectively with it.* The availability of any animal for food, leaving out consideration of size, will depend upon :

1. The habits and activity of the organism itself;

2. The habits and activity of the fish.

This will vary :

1. For the same organism with different fishes; and

2. For different organisms with the same fish.

This variation of habit also affects grab samples, although it is impossible here also to obtain data by means of which its magnitude can be estimated and allowed for. A grab sample, in the opinion of the writer, must not be taken as a true or even approximate measure of the absolute numbers of animals present upon the sea bottom. In the Plymouth waters, at any rate, it is a differential sample of the organisms, ranging from 100 per cent (e.g. small Lamellibranchs and Gastropods, Echinocyamus pusillus, Ophiothrix fragitis) downwards (e.g. Upogebia, tubicolous Polychætes, Portunus depurator), according to their several abilities to elude the sampler. When considering grab results, this must always be borne in mind. In view of these facts, to work out the rough weights and dry weights of the organisms captured in the bottom sampler on the " corner " grounds, and to deduce therefrom the total amounts of the different types of food available over the area did not seem to be justified.

\section{FOOD AND FEEDING HABITS OF FISHES.}

\section{General.}

Examination of the stomach contents of fishes actually caught upon the grounds investigated by grab and trawl revealed that Ogilvie's statement with regard to post-larval herrings holds good in a general way

* See also 19 , p. 67 , lines 7-10. 
for all fishes-i.e. "within limits determined by size and suitability in other respects, the fish will eat what they can get " $(18, p .10)$. This fact is clearly demonstrated by examining fishes from grounds on which different bottom-dwelling animals predominate. For example, Portunus depurator is common on the "corner" grounds, while Corystes cassivelaunus and Atelecyclus septemdentatus are rarely found. But farther out in the direction of the Eddystone, Corystes and Atelecyclus, though not numerous, are fairly common and $P$. depurator less abundant. This change of fauna is reflected in the food of Gadus luscus, Raia clavata, and Sycliorhinus canicula trawled from those two areas (Table I).*

TABLE I.

Difference in Food of Gadus luscus, RaIA clavata, and Soylio. RHINUS CANIOULA ON "Corner" and OUtside Grounds.

\begin{tabular}{|c|c|c|c|c|c|}
\hline & \multicolumn{4}{|c|}{ Stomachs containing } & \multirow{3}{*}{$\begin{array}{c}\text { Total } \\
\text { number of } \\
\text { stomachs } \\
\text { examined }\end{array}$} \\
\hline & \multicolumn{2}{|c|}{$\begin{array}{l}\text { Portunus } \\
\text { depurator }\end{array}$} & \multicolumn{2}{|c|}{$\begin{array}{l}\text { Corystes and/or } \\
\text { Atelecyclus }\end{array}$} & \\
\hline & Number & $\%$ & Number & $\%$ & \\
\hline \multirow{2}{*}{ Gadus luscus $<$} & 60 & $36 \cdot 8$ & 4 & $2 \cdot 5$ & 163 \\
\hline & 19 & $25 \cdot 7$ & 16 & $21 \cdot 6$ & 74 \\
\hline Raia clavata< Corner & 65 & $38 \cdot 9$ & 9 & $5 \cdot 4$ & 167 \\
\hline Outside & 12 & $24 \cdot 5$ & 18 & $36 \cdot 7$ & 49 \\
\hline \multirow{2}{*}{ Scyliorhinus canicula $<$} & 18 & $11 \cdot 8$ & 1 & $0 \cdot 7$ & 152 \\
\hline & 7 & $11 \cdot 3$ & 13 & 21.0 & 62 \\
\hline
\end{tabular}

When, therefore, the food of the entire fish population of any particular area is considered as a whole, the organisms most commonly eaten are (with certain exceptions such as Echinodermata and Cœlenterata) found to be those most numerous and/or easily available. This does not apply, of course, to every species of fish considered individually, because for one reason or another some fishes are "selective" feeders: i.e. they are fitted by structure or habit to catch and eat certain animals and not others, when they are said to "select" the former and "reject" the latter.

A noteworthy feature of the "corner" grounds at the present time is the great scarcity of all kinds of Flatfishes except Pleuronectes microcephalus (the Lemon Dab) and Arnoglossus laterna (Scaldback). Only very occasionally are Sole, Brill, Turbot, and Flounder taken in the trawl, and Dab and Plaice are almost equally scarce. The absence of the last-named fish may be due to a corresponding paucity in the Lamellibranch, and in fact, the entire Molluscan fauna within the area. Although quantitative records are lacking, there is little doubt that during a

\footnotetext{
* See also 2, p. 46, par. 2.
} 
number of years immediately following the War Aequipecten opercularis (Queens)* at any rate was abundant. Plaice were then also numerous.

There is some indication that Queens are again on the increase. Should they once more populate the area it will be interesting and instructive to observe whether or not Plaice also return in numbers to the grounds.

The Lemon Dab (Pleuronectes microcephalus), though not abundant, is fairly numerous. $\uparrow$ This may possibly be due to the fact that its diet consists mainly of Polychæta, the numbers of which probably have remained undiminished in spite of intensive trawling over the area.

The Scaldback (Arnoglossus laterna)--unfortunately not a marketable fish-is very plentiful. This again is probably to be explained by the presence of an abundant supply of suitable food organisms-Amphipoda, Schizopoda, Crangonidæ, Pandalidæ, and Crystallogobius nitssonii.

\section{Periodic Change of Food.}

As would be expected from the constancy of the constitution of the invertebrate fauna throughout the year, there is little obvious change of food in the summer and winter seasons. Nevertheless, there is, in certain cases at least, a definite periodic change. The Whiting, for example, normally feeds on a wide range of animals, its diet including large and small Crustaceans of all kinds, Worms and small Fishes (including the young of its own species), and an occasional Mollusc and Echinoderm. But Whiting of all sizes from $10 \mathrm{~cm}$. in length upwards, caught in May and June, 1929, were found to be feeding almost exclusively on the Megalopa larvæ of Corystes cassivelaunus. Of fishes between 10 and $15 \mathrm{~cm}$., twenty-five were examined. Two of those had their stomachs empty : all the others had been feeding on the larvæ. Of fishes over $15 \mathrm{~cm}$. in length, fifty specimens were examined, forty-seven of which had been feeding on the Megalopas, thirty-three of them exclusively. In many cases the stomachs of the fish were simply gorged with the larvæ, some counts recording over 200 individuals per stomach.

The Whiting, in Plymouth waters, is a migratory species. Small fish appear in numbers from about May onwards, the larger fish following later in the season. A few may remain in the neighbourhood throughout the year. The fact that the time of their reappearance in numbers in the Plymouth area this year coincided with the presence of immense shoals:

* Local fishermen state that trawling for Queens on and to the eastward of this area yielded very large hauls of the bivalves. Now they are so scarce that a whole day's takings would fall far short of an hour's catch in those years.

$\dagger$ This fish also is not quite so plentiful as formerly.

‡ One of these shoals was encountered in a small boat at sea about noon on the 20 th May, 1929. For several miles the Megalopas were so numerous near the surface that two or three at a time could be scooped up in an ordinary cocoa-tin. A striking feature of the shoal was that all the larvæ were swimming rapidly, and all in the same direction. 
of Corystes Megalopas in these waters, and that when caught the Whiting were found to be feeding almost entirely on the larvæ, suggests the possibility that the fish may have been attracted by this abundance of food. This view cannot definitely be put forward, however, without further evidence gleaned over a number of years.

Nineteen Whiting between 5 and $10 \mathrm{~cm}$. in length were captured. Of these, two had empty stomachs, and seventeen had been feeding on small fishes, mostly Crystallogobius nilssonii, but one $(9 \mathrm{~cm}$.) had taken a Mackerel Midge (Onos sp.). Only two had eaten Megalopas, the stomach of one containing two and the other three individuals. The reason why these very small Whiting had not been feeding on the larvæ, as had the larger sizes, is not apparent.

\section{Correlation of Habit and Structure with Food Eaten.}

The habits of fishes - as of all animals-are inextricably bound up with structure and structure with habit. How the one affects the other does not concern us here. But both are important factors, influencing to a great extent the type of animal upon which a fish will normally depend for food. Because of their intimate relationship, therefore, the parts played by these two factors in determining the staple food of different fishes will be considered together.

The prey which a fish can capture is dependent to a large degree upon its feeding habits or foraging methods. These differ markedly in different fishes, and there is found always to be a corresponding difference in the type of organisms which form their staple food. This can best be illustrated by studying closely certain fishes with very typical and contrasting methods of feeding.

The Lemon Dab (Pleuronectes microcephalus). On the "corner" grounds the Lemon Dab feeds exclusively upon Annelids. This is entirely in keeping with the habits of the fish. It is a frequenter of muddy bottoms where worms are abundant and other organisms correspondingly scarce. Tubicolous Polychætes, which form the bulk of the Annelid fauna, cannot be captured by lying in wait for them : they have to be hunted and that discreetly, otherwise they disappear to safety down their tubes. So the Lemon Dab, if observed in an aquarium tank, is found to be of a very restless disposition. It is constantly on the move, swimming for short distances with intervening halts for brief periods. It comes to rest in a characteristic attitude, with the head and forepart of the body raised well off the substratum. Remaining perfectly still in this position, the fish, by means of its very prominent and exceedingly movable eyes, scans the bottom in its immediate neighbourhood (Fig. 1). Should it then observe a food organism-i.e. the anterior end of a worm cautiously emerging 
from its burrow-the Lemon Dab suddenly pounces upon it like a true hunter with a kind of forward leap, bringing its mouth down almost vertically upon its victim by a strong arching of the anterior part of the
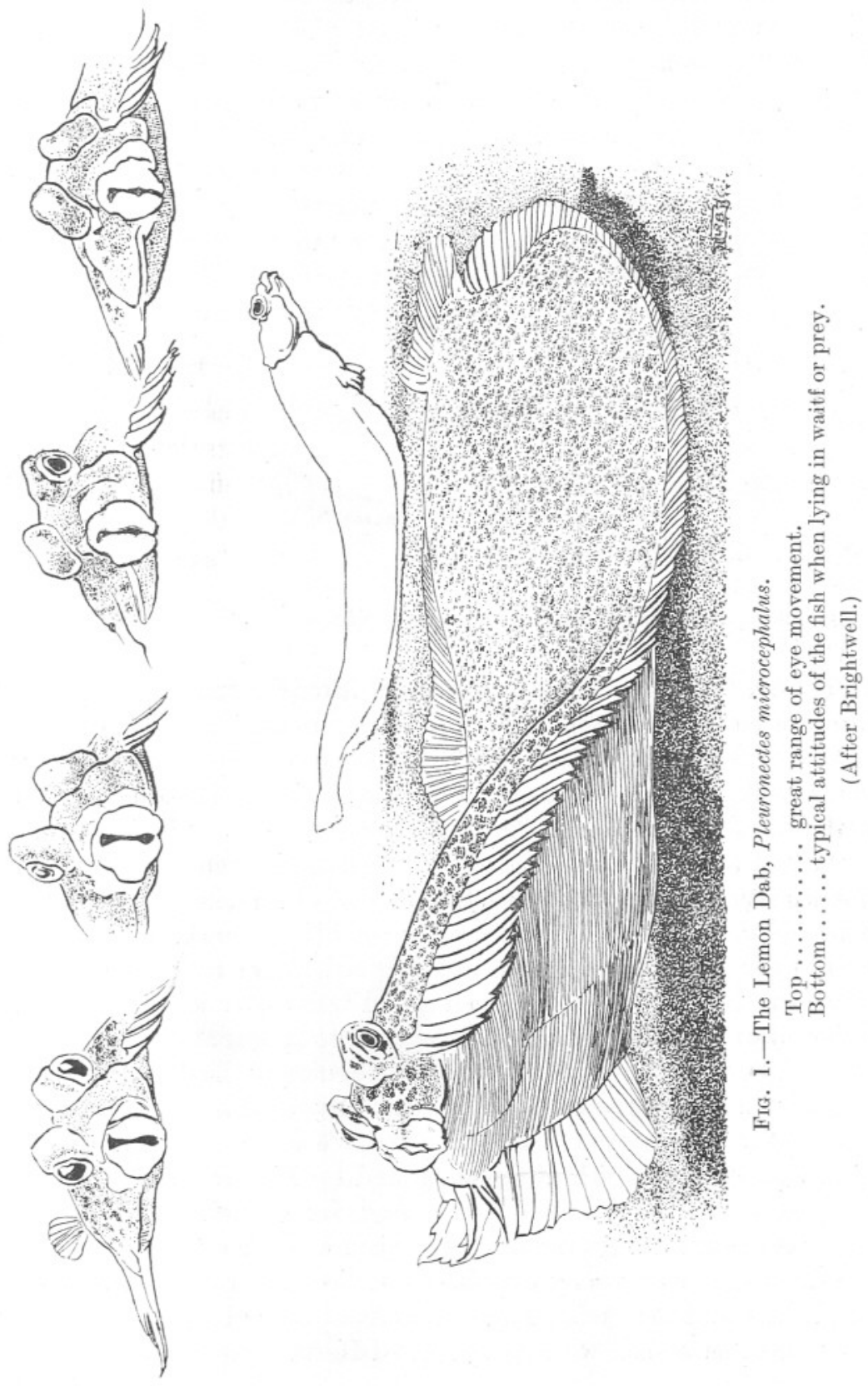
body (Fig. 2). Foraging thus, it is not surprising that Todd (29, p. 104), during his researches upon the food of fishes in the Southern North Sea, should have found that the Lemon Dabs of that area were feeding to a considerable extent upon a species of Cerianthus.

It is somewhat strange, however, that of all these fishes from the "corner" grounds which have been examined, not one contained the slightest trace of a Lamellibranch. This may possibly be due to the great scarcity of these Molluses in this area. On the other hand, there is every indication that the Lemon Dab does not " bite" its food. The nipped-off ends of tubicolous Polychætes are seldom or never found in its stomach: the whole worm is withdrawn unbroken from its burrow or tube. This being so, large Lamellibranchs perhaps are powerful enough to pull their siphons out of the fish's mouth even if they are caught. Small ones may

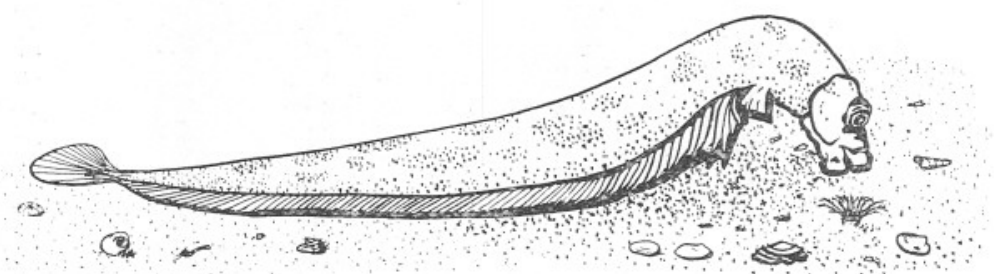

Fig. 2.-A Lemon Dab in the act of pouncing upon a tubicolous worm.

not be able to do so, but as the fish is not fitted for crushing hard shells, these are probably rejected when the valves are drawn into its mouth.

Ramsay Smith (23, p. 213) found that while Annelids formed the chief food of Lemon Dabs in the Firth of Forth, Hermit Crabs-Eupagurus bernhardus and Anapagurus lavis-also entered largely into their diet. In view of this statement, a number of small Hermits were introduced into aquarium tanks containing Lemon Dabs in order to observe what would happen. The fish immediately set about hunting the crabs in exactly the same manner as that described above for the capture of tubicolous Polychætes. With head raised well above the crab, the fish waits and watches until the Hermit ventures to appear at the mouth of its shell and then suddenly pounces upon it. Generally the crab shoots back to safety too quickly to be taken, as it usually walks about with only the tips of its walking legs and chelæ exposed. Moreover, the fish has to lie in wait facing the mouth of the shell, and the Hermits were frequently observed to dart back before emerging far enough even to crawl, having seen that danger threatened as soon as their eyes - conveniently placed on the tips of long eye-stalks-projected far enough to see up round the lip of the shell. The Lemon Dabs hunted more successfully, however, when a shell with its contained Hermit happened to be over- 
turned. The crab is then obliged to expose much more of its body in its efforts to regain a normal position. In these circumstances, a fish was occasionally able to stalk and capture an unlucky Hermit. There seems then to be little doubt that small Pagurids would figure much more prominently in the diet of the Lemon Dab were it not for their extreme wariness and ability to beat a hasty retreat into the safety of their shells. On the "corner" grounds off Plymouth, the worm fauna appears to be large enough to support the Lemon Dabs of the area without their having to hunt such elusive prey. At any rate, small Hermits, though abundant, are not eaten.

The Sole (Solea vulgaris). The feeding habits of the ordinary Sole are very different from those of the Lemon Dab, and there is a corresponding difference in its diet. In foraging for prey the true Sole depends almost entirely on the tactile sense. The eyes, unlike those of the Lemon Dab which hunts by sight, are very small and scarcely movable. But the fish is provided with a dense mass of tactile villi on its lower cheek, which is thus equipped to function as a very sensitive tactile organ. When in search of food, the Sole creeps very slowly over the bottom using its lateral fins more for walking than for swimming, the fin spines in their motion resembling very much the legs of a centipede. As it moves along, the fish thoroughly explores the substratum by what may be described as a kind of patting and grubbing action of the snout, carefully feeling the objects in its path with the sensitive papillæ on its lower cheek. Bateson (1, p. 240) states that, so far as he could determine, the Sole is unable to find food which does not lie on the bottom, and will not succeed in finding food suspended in the water close above it unless it is lowered so that the fish is able to cover it with the lower surface of its head, when it is seized at once.

Unfortunately, Solea vulgaris was not obtainable in sufficient numbers from the " corner" to enable any definite conclusion to be drawn as to its staple food. But it may be significant that the few which were examined had been feeding on Eulalia, Phyllodoce, Porcellana longicornis, and Mollusca. Todd (29, p. 117), however, examined 212 stomachs containing recognisable food material. Of these, Polychæta were present in 59 per cent, Crustacea in 30 per cent, Pisces and Mollusca each in 11 per cent, Echinodermata in 9 per cent, Nemertinea in 3 per cent, and Polyzoa and Cœlenterata in less than 0.5 per cent. The principal food species were :-

Polychæta: Lagis koreni, Ophelia limacina, Nephthys sp., and Sabellaria spinulosa.

Crustacea: Ampelisca sp.

Mollusca: $\quad$ Scrobicularia $(=$ Syndosmya) alba.

Pisces: $\quad$ Pleuronectes limanda $(1 \cdot 9-2 \cdot 8 \mathrm{~cm}$.), Ammodytes sp.

Echinoderms: Echinocyamus pusillus. 
It will at once be seen that all the above animals are such that a Sole, foraging for food in the manner described, might be expected to find and contrive to capture. The worms eaten, for example, are either freeliving forms which creep over the sea bottom or, if tubicolous, are sluggish and vulnerable species such as the Pectinaridæ which inhabit shallow and friable tubes.

It has not been found possible to study the feeding habits of the other species of Sole, but it is probable that they all adopt essentially the same methods, all having sensitive papillæ developed to a greater or less extent on the lower cheek.

Besides the structural differences already mentioned, the Lemon Dab and Sole exhibit still other morphological modifications correlated with their modes of feeding. The Lemon Dab has a very small terminal mouth, with teeth on both sides, but best developed on the lower side. In the Sole, on the other hand, the mouth is not terminal, but curved down ventrally, and teeth are present only on the lower side. The Lemon Dab depends entirely upon the visual sense in foraging for its prey and is therefore a day feeder. The Sole is almost, if not quite, independent of vision for the finding and recognition of its food, and feeds mostly at night.

Dab and Plaice (Pleuronectes limanda and P. platessa). Both are visual feeders. The former forages in a manner similar to that of the Lemon Dab, but does not raise itself quite so far off the bottom or bring its mouth down upon its prey at such a steep angle. It shoots upon them more from a horizontal direction, and being an active and alert fish it is thus able to capture a greater range of organisms than the Lemon Dab, but is less successful when it comes to Polychætes alone. The hunting posture of the Plaice is still more nearly horizontal, the head being raised off the bottom even less than that of the Dab. Its food is therefore again more restricted in its range, approaching that of the Sole-i.e. Mollusca, errantiate Polychætes, and sometimes a few Crustaceans, including an occasional Upogebia.

Among Flatfishes, the direct effect of structure in determining the kind of food which is eaten is also clearly seen in the post-larval stages, which do not come within the scope of this work. Lebour (13, p. 443), however, has shown that young Pleuronectids fall into two groups according to the structure of the alimentary canal. One group includes Solea vulgaris, S. variegata, S. lascaris, Pleuronectes limanda, Rhombus maximus, R. lavis, Zeugopterus punctatus, Z. unimaculatus, and Scophthalmus norvegicus, each of which possesses a large mouth and short thick gullet and stomach. Very soon after hatching these fishes all feed upon small Copepoda and Cladocera. The second group includes Pleuronectes flesus, P. microcephalus, and Arnoglossus laterna, which have a small mouth and 
long narrow gullet and stomach. These do not eat Copepods or any other Crustacea until a greater size is reached, subsisting at first largely on a vegetarian (Diatom) diet, and going on to Entomostraca only at a much later stage.

The Gurnards. Definite correlation between the habits of a fish and its staple food organisms is also well seen in the case of the Gurnards. Four species-Trigla lineata, T. cuculus, T. gurnardus, T. hirundo - are present in small numbers in the Plymouth area. If these four species be observed in aquarium tanks, they will be found to form a definite habitudinal series. T. lineata spends most of its time crawling over the bottom of the tank by means of its long finger-like pectoral filaments. In addition to their locomotor function, the filaments are also very efficient tactile organs used in the finding and identification of food. As the fish creeps slowly over the bottom, the filaments are kept in continuous motion thoroughly " fingering" the ground over which they pass. When anything which promises to be suitable as an article of diet is touched by one of the filaments, the fish suddenly wheels round upon it and either immediately swallows it, or subjects it to still further tactile "scrutiny." T. cuculus, T. gurnardus, and T. hirundo also possess pectoral filaments and use them in the manner described, but to a progressively less extent. These species depend more and more upon the visual sense for the recognition of their prey, and dart upon it from a distance. Thus we find that $T$. lineata feeds very largely upon Porcellana longicornis, and to a less extent upon Galathea, Portunus pusillus, and Amphipoda. Burrowing organisms such as Upogebia and those tubicolous Polychætes which retract with almost lightning-like rapidity on the slightest provocation do not figure in its diet any more than do such active swimmers as the Pandalidæ, Crangonidæ, Palæmonidæ, or Pisces. But those agile organisms which successfully elude capture by $T$. lineata fall easy victims to the three other species which are more active hunters, depending less upon the tactile than upon the visual sense in foraging for their prey.

The Dragonet (Callionymus lyra). Callionymus lyra, too, is an interesting feeder whose habits are clearly reflected in its diet. This fish, a bottom dweller, is continually in a state of restless activity, in this somewhat resembling the Lemon Dab. For a few moments it will remain still, the anterior part of its body raised slightly off the ground as the fish rests poised upon its large pectoral fins. Then it skims along for a short distance, swimming usually less than a centimetre off the bottom, and again comes to rest. In this way Callionymus explores thoroughly a large and representative area of the sea floor, and few organisms escape its attention. Its food, therefore, is varied in the extreme. Ophiuroids, small Echinoids such as Echinocyamus pusillus and the young of larger species, 
all the bottom-living Crustacea of suitable size- e.g. Amphipoda, Schizopoda, Porcellana, Galathea, Upogebia (occasionally), Paguridæ, Portunus pusillus, Ebalia, Inachidæ-small Mollusca of every description, and errantiate Polychæta are all to be found in the stomachs of Callionymus. Tubicolous Polychætes appear generally to elude it. Palæmonid, Crangonid, and Pandalid Crustaceans, too, it seldom captures, perhaps because they are too alert, but more probably because they live as a rule just above the bottom in a plane which Callionymus does not frequent (see also p. 693).

Other Fishes. The feeding habits of the other fishes from the " corner" have not been studied in detail. Of such forms as the Gadoids little can be

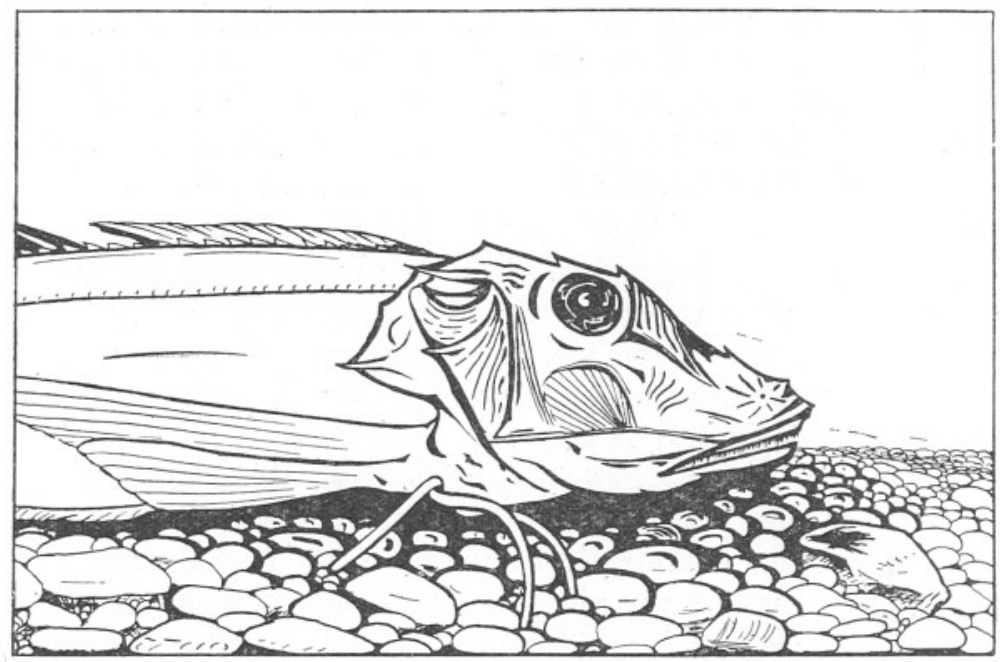

Frg. 3.-Trigla hirundo "feeling " its way along the sea floor by means of its long finger-like pectoral filaments.

added to what is already generally known. They are roving fishes which feed by sight, but some of them, such as the Pouting and Cod, appear to use their barbel as a tactile or gustatory organ. They will snap at almost anything which comes within their reach, whether on or off the bottom. Thus their food is almost as varied as the fauna of the area in which they are living. On the "corner" grounds only Whiting (Gadus merlangus), Whiting Pout (G. luscus), and the Poor-cod or Bib (G. minutus) are taken in any numbers. The first-named fish, while it feeds both on and off the bottom, confines its attention mostly to actively swimming pelagic organisms, while the two others graze more upon the bottom-dwelling animals (Table V).

Of the Dogfishes only two species have been taken during these 
investigations. The feeding habits of these voracious members of the Shark tribe are also well known. The Rough Dogfish (Scyliorhinus canicula) feeds on anything which comes in its way. It hunts by scent, and although remaining for the most part in the lower layers also scours the sea from bottom to surface. The Spur Dog (Squalus acanthias), on the contrary, feeds while in Plymouth waters almost entirely on Herring. In fact it is present in numbers in the Plymouth area only during the winter months when Herrings are abundant. Todd (29, p. 132), however, states that in the North Sea its diet is much more comprehensive, including besides Pisces, Crustacea, Gephyrea, and often large quantities of Pleurobrachia pileus.

The four species of Ray examined feed almost entirely on the various Crustaceans available in their neighbourhood. Of their actual methods of feeding nothing has been seen.

\section{Bionomics.}

Elton (6, p. 59), in discussing food chains, states that they stop at certain points because there are very definite limits, both upper and lower, to the size of food an animal can eat. The size of the prey of carnivorous animals (both terrestrial and aquatic) is limited in the upward direction by their strength and ability to catch the prey, and in the downward direction by the feasibility of getting enough of the smaller organisms to satisfy their needs, the latter factor being also strongly influenced by the numbers as well as the size of the food animals. There is therefore an optimum size of food which is the one usually eaten. In the sea, however, another very important factor is involved which Elton does not mention possibly because it is very much less evident on the land. Animals of a suitable size for food, although living in the same area, may move in quite a different plane from that frequented by the carnivore and so, being inaccessible, remain outside a food chain from which size alone does not preclude them. During the time that the Megalopa Larvæ of Corystes were swarming in Plymouth waters, all the fishes which could catch them were feeding upon them to a greater or less extent. But Callionymus lyra was feeding on them not at all. There is no reason to suppose that this fish would not or could not eat the larvæ had they been available to it. The Megalopas, judging from the type and size of the other organisms which Callionymus will devour, are not too large or too small to suit it, nor is the fish too sluggish to catch them. But, so far as can be determined from observations on the habits of the fish, it never in ordinary circumstances leaves the bottom to feed. Therefore Megalopas swarming in the waters above it (21, p. 602) would not come within its range at all. Rays also are largely bottom feeders, but they will not infrequently rise off the ground in pursuit of food. Thus they, 
the younger stages especially, made use of the Megalopas during the short time that they were abundant in the sea (Table II, p. 695).

Aquatic carnivores differ also from the majority of terrestrial forms in that they show a marked change of food (prey) with growth. This is due to at least two important factors. The first is that the larval fish must "fend for itself" from the time that the yolk-sac is absorbed, or even before, being entirely dependent upon its own efforts for the capture of its food. These little juvenile fishes must of necessity feed upon organisms proportionate to their size, which may be the young stages of the same food animals that support the adult fish or entirely different organisms. The food and feeding habits of the larval and post-larval stages of fishes have been very fully investigated by Lebour (op. cit.) and need not therefore be detailed here. Gradual change in the optimum size of food with growth continues until the adult size is reached. Todd (29) states that young Cod in the North Sea feed wholly on Crustacea, chiefly Ampelisca. With increase in size, their diet includes other groups, especially Pisces, Mollusca, and Polychæta. Young Plaice $(<10 \mathrm{~cm}$.) feed chiefly on Crustacea (Amphipoda, etc.) and Polychæta. With increase in size, Mollusca take first place. Such examples need not be multiplied. Among fishes captured on the "corner" grounds, change of food with growth was most obvious in two species of Ray-Raia clavata and $R$. maculata. The food of the young stages $(20-40 \mathrm{~cm}$.) consisted mainly of small Crustacea, chiefly Ampelisca.* Larger fish fed less upon Ampelisca and depended more upon other larger Crustacea. Eventually, in the largest fish, Amphipoda disappear entirely from their diet (Table II).

The prey of many terrestrial carnivores, on the other hand, changes but little or not at all during their growing period for the simple reason that they do not hunt. To begin with, the young of predatory mammals, for example, are fed upon maternal milk. Later on, the parents forage on their behalf, carrying home prey to the lair to feed them. Thus the growing animal does not have to hunt for itself until, from the point of view of foraging for food, it has become an adult and can catch the normal prey of the species. This applies also to birds. The nestlings are fed either upon semi-digested regurgitations from the stomach of the parent (e.g. Penguins) or are supplied liberally with food brought back by the old birds to the nest. In short, the higher terrestrial carnivores at least, do not have to depend upon their own efforts from the moment of their birth. This the little fish is obliged to do or die.

In the sea, another important factor bringing about change of food with growth is, in many cases, the change of level or environment frequented by the growing fish at different stages of its development. It

* During the time that Corystes Megalopas were abundant, young Rays $(20-30 \mathrm{~cm}$. were feeding largely upon them (Table II). 


\section{TABLE II.*}

FOOD OF RAIA CLAVATA AND RAIA MACULATA.

Total number of Organisms in all Stomachs Examined.

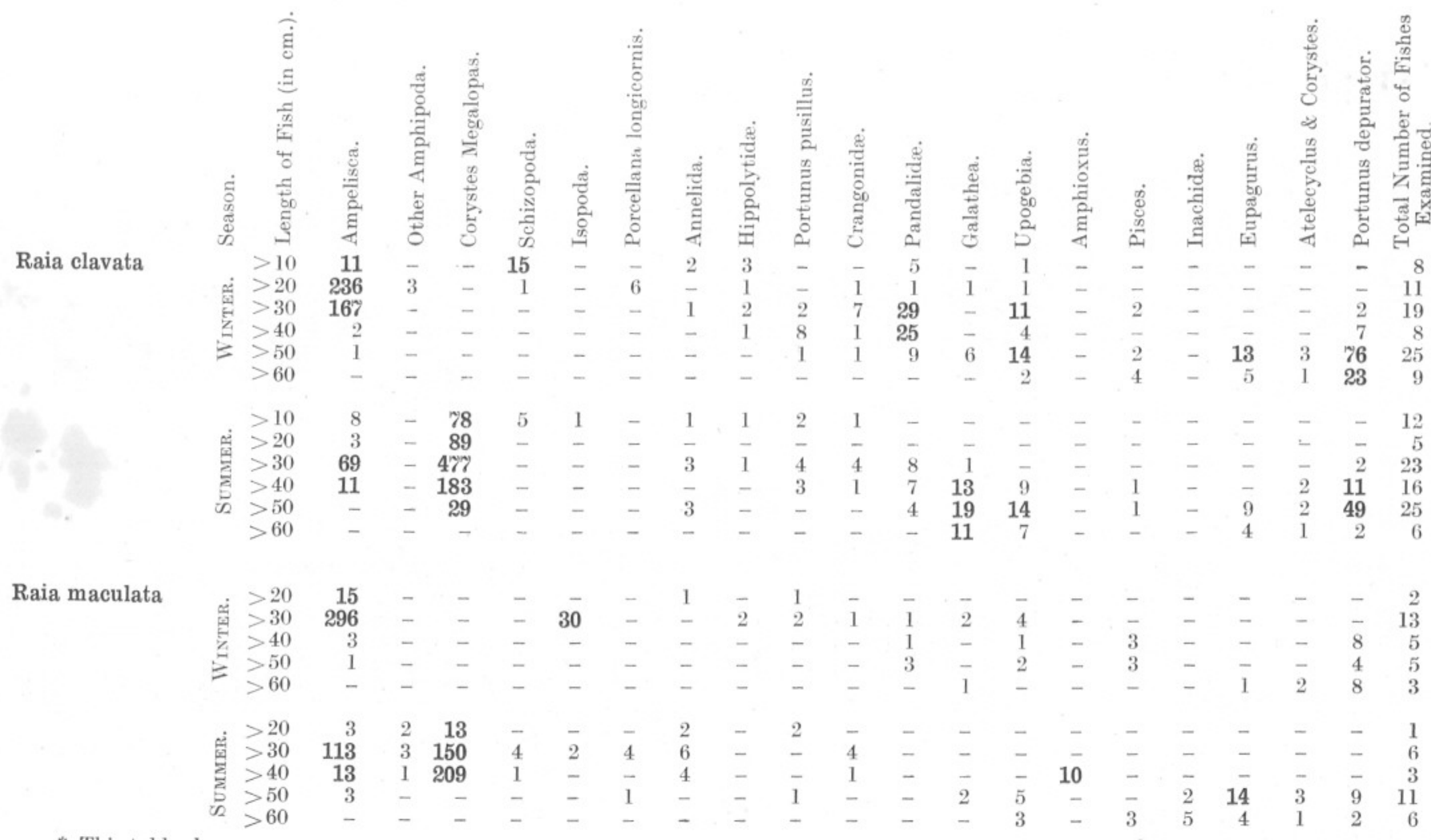

* This table shows:-

(a) Gradual change of food with growth.

(b) That Ampelisca was abundantly available to the Rays in the winter season when few were taken in the bottom sampler.

(c) That the younger stages preyed largely upon Corystes Megalopas when these larvæ were swarming in the area in summer. 
will suffice to quote one example. Young Pleuronectidæ before metamorphosis are active members of the marine macro-plankton, feeding greedily upon other plankton organisms of suitable size. Later, when metamorphosis sets in, they descend to the sea bottom and there remain lying on one side for the rest of their lives. It is obvious, therefore, that apart altogether from any change imposed by increase in size, there must follow a complete change of food due to change of environment and therefore of available food organisms.

\section{BIBLIOGRAPHY.}

1. Bateson, W. The Sense-organs and Perceptions of Fishes; with Remarks on the Supply of Bait. Jour. Mar. Biol. Assoc., N.S., Vol. I, No. 3, p. 225, 1890.

2. Blegvad, H. On the Food of Fish in the Danish Waters within The Skaw. Rep. Danish Biol. Sta., XXIV, p. 17, 1916.

3. Continued Studies on the Quantity of Fish Food in the Sea Bottom. Rep. Danish Biol. Sta., XXXI (1925), p. 27, 1926.

4. Q Quantitative Investigations of Bottom Invertebrates in the Limfjord 1910-1927 with Special Reference to the PlaiceFood. Rep. Danish Biol. Sta., XXXIV (1928), p. 33, 1928.

5. Cunningham, J. T. A Treatise on the Common Sole (Solea vulgaris). Mar. Biol. Assoc., Plymouth, 1890.

6. Elton, Charles. Animal Ecology. Sedgwick \& Jackson, London, 1927.

7. Ford, E. On the Growth of some Lamellibranchs in Relation to the Food-supply of Fishes. Jour. Mar. Biol. Assoc., N.S., Vol. XIII, No. 3, p. 531, 1925.

8. Hertuing, H. Untersuchungen über die Ernährung von Meeresfischen. I. Quantitative Nahrungsuntersuchungen an Pleuronektiden und einigen anderen Fischen der Ostsee. Ber. deutsch. wiss. Komm. Meeresforsch., Berlin, N.F./Bd. IV/Heft 2, p. 25, 1928.

9. Hunt, O. D. The Food of the Bottom Fauna of the Plymouth Fishing Grounds. Jour. Mar. Biol. Assoc., N.S., Vol. XIII, No, 3, p. 560,1925 .

10. Jensen, P. Boysen. Valuation of the Limfjord. I. Studies on the Fish-food in the Limfjord 1909-1917, its Quantity, Variation, and Annual Production. Rep. Danish Biol. Sta., XXVI, p. 1, 1919. 
11. Jensen, Aage J. C. The Relation between the Size of the Plaice Stock and the Quantity of "First Class Plaice-Food" in certain Parts of the Limfjord. Rep. Danish Biol. Sta., XXXIV, p. 87, 1928.

12. Kemp, Stanley. The Decapoda Natantia of the Coasts of Ireland. Fisheries, Ireland, Sci. Invest., 1908, I, (1910).

13. Lebour, M. V. The Food of Post-Larval Fish. Jour. Mar. Biol. Assoc., N.S., Vol. XI, No. 4, p. 433, 1918.

14. - Feeding Habits of Some Young Fish. Jour. Mar. Biol. Assoc., Vol. XII, No. 1, p. 9, 1919.

15. — The Food of Post-Larval Fish. No. II (1918). Jour. Mar. Biol. Assoc., Vol. XII, No. 1, p. 22, 1919.

16. The Food of Young Fish. No. III (1919). Jour. Mar. Biol. Assoc., Vol. XII, No. 2, p. 261, 1920.

17. Murie, James. Report on the Sea Fisheries and Fishing Industries of the Thames Estuary. Waterlow Bros. \& Layton, London, 1903.

18. Oginvie, Helen S. Observations on the Food of Post-Larval Herring from the Scottish Coast. Fisheries, Scotland, Sci. Invest., 1927, I, 1927.

19. Petersen, C. G. JoH., and P. Boysen Jensen. Valuation of the Sea. I. Animal Life of the Sea-bottom, its Food and Quantity. Rep. Danish Biol. Sta., XX, p. 3,-1911.

20. Pefersen, C. G. JoH. The Sea Bottom and its Production of FishFood. Rep. Danish Biol. Sta., XXV, p. 1, 1918.

21. Russeld, F. S. The Vertical Distribution of Marine Macroplankton. V. The Distribution of Animals Caught in the Ring-trawl in the Daytime in the Plymouth Area. Jour. Mar. Biol. Assoc., Vol. XIV, No. 3, p. 557, 1927.

22. Scott, Thomas. Observations on the Food of Fishes. Twentieth Annual Rept. Fish. Bd. for Scotland, Pt. III, p. 486, 1902.

23. Smith, W. Ramsay. On the Food of Fishes. Tenth Annual Rept. Fish. Bd. for Scotland, Pt. HI, p. 211, 1892.

24 Sömme, $\mathrm{J}_{\mathrm{ACO}} \mathrm{D}$. Faunistische und Quantitative Studien über Polychaeten aus dem Lenefjord und dem Grönsfjord (südliches Norwegen). Medd. Zool. Mus. Oslo, Nr. 11, p. 103, 1927. 
25. Tchugunov, N. L. Essay on the Quantitative Exploration of the Benthos-production in the North part of the Caspian Sea and of the Typical Basins of the Volga-delta. Rep. Ichthyol. Lab. Astrachan, V, No. 1. (Original paper in Russian.)

26. Тттсомв, Јонм W., and C. M. McCay. The Nutritional Requirements and Growth Rates of Brook Trout. Trans. Amer. Fish. Soc., Vol. 58, p. 205, 1928.

27. Topd, R. A. Notes on the Invertebrate Fauna and Fish-food of the Bays between the Start and Exmouth. Jour. Mar. Biol. Assoc., N.S., Vol. VI, No. 4, p. 541, 1903.

28. - Report on the Food of Fishes Collected during 1903. Internat. Fish. Investigations. Mar. Biol. Assoc., Report I (Southern Area), 1902-1903 (Cd. 2670), p. 227, 1905.

29. Second Report on the Food of Fishes (North Sea, 1904-1905). Internat. Fish. Investigations. Mar. Biol. Assoc., Report II (Southern Area), Pt. I, 1904-1905, (Cd. 3837), p. 49, 1907.

30. Wilson, Gregg. Notes on How Fish find Food. Rept. Brit. Assoc., 1893, p. 548, 1894. 


\title{
APPENDIX.
}

\author{
TABLES III, IV, AND V. \\ Explanation of Tables.
}

Table III. Bottom Sampler Hauls.

In this table is recorded the number of individuals or homogeneous groups of animals brought up from 0.5 square metre of bottom in five hauls of the $0 \cdot 1$ square metre bottom sampler at all stations 1-15. (See Chart, p. 678.)

The type of soil* at each station is indicated. Seasonal observations are tabulated under the heading a, b, c, d for autumn 1928, and the following winter, spring and summer respectively.

Points of special interest in this table are :-

(a) The relatively large Polychæte fauna of the area (see p. 689).

(b) The almost complete absence of Ampelisca in the winter season in bottom sampler hauls (see p. 681).

(c) The more or less uniform distribution of Upogebia spp. over the whole area as recorded by the bottom sampler-probably only a small fraction of the whole population (see p. 682).

(d) Mollusca are poorly represented on this ground.

(e) Portunus depurator is not recorded at all by the bottom sampler.

(f) That there is little or no change in the infauna as a whole over the year.

In this and the following table, where for various reasons actual counts were impracticable or impossible, the following signs have been used.

$$
\begin{aligned}
& +=\text { Fragments only of the animal were obtained. } \\
& \oplus=\text { Present, but not counted. } \\
& ++=\text { Present. }
\end{aligned}
$$

Table IV. Trawl Samples.

This table records the number of individuals or homogeneous groups of the epifauna per $\frac{1}{4}$ acre of bottom as brought up by the "Agassiz" trawl. Four $\frac{1}{4}$-acre hauls are given for each of stations $3,10,12$, and 14 towing north, south, east, and west (N.S.E.W.) in turn from each of these centres. Three seasons' observations are indicated, as explained for Table III, by the letters $\mathrm{b}, \mathrm{c}, \mathrm{d}$ at the heads of the columns.

Points of special interest brought out by this table are :-

(a) The relative abundance of Pandalina brevirostris, and the migratory movements thereof (see p. 680).

* Detailed analyses of the soils have not been made, but samples are preserved so that this can be done later if necessary. 
(b) Portunus depurator is very common on the ground, although not one was captured by the bottom sampler.

(c) A sudden appearance of Acanthodoris pilosa around station 3 when the summer series of observations was taken; other Nudibranchs also more numerous.

(d) Crangon vulgaris is most numerous on the ground in winter, having left its summer haunts closer inshore. Pontophilus spinosus is also present in greatest numbers at this season.

(e) Scarcity of Corystes cassivelaunus and Atelecyclus septemdentatus. In this connection, cf. Table I, page 684 .

\section{Table V. Food of Fishes.}

Here are tabulated the results of detailed examinations of stomach contents of fishes taken in an "Otter" Trawl within the "corner" area. The number of stomachs containing different organisms is given for different sizes of each fish, as well as the total number of each size-group examined. The numbers have not been worked out as percentages as this would tend to give a false value to observations on small numbers of fish. Although an attempt was made to examine at least twenty-five specimens of each species, this was possible only in the case of fishes which are sufficiently numerous on the ground. Of other species, less common or rare, the numbers examined were determined by the numbers caught.

Comparable winter and summer observations have been made, and are recorded separately in the upper and lower (italicised) columns respectively, opposite each size-group.

This table shows :-

(a) The food organisms preyed upon by the different fishes of the area (reading across).

(b) The various fishes which feed upon any particular animal (reading vertically).

(c) That the food of some fishes is restricted to certain organisms. This is determined by their structure or methods of foraging as explained in the text (p. 686).

(d) The importance of Corystes Megalopas as food for Whiting (over $10 \mathrm{~cm}$.) and young Rays when these larvæ are available; small Whiting under $10 \mathrm{~cm}$. in length did not feed to any extent upon the larvæ at a time when all the larger sizes were doing so. 


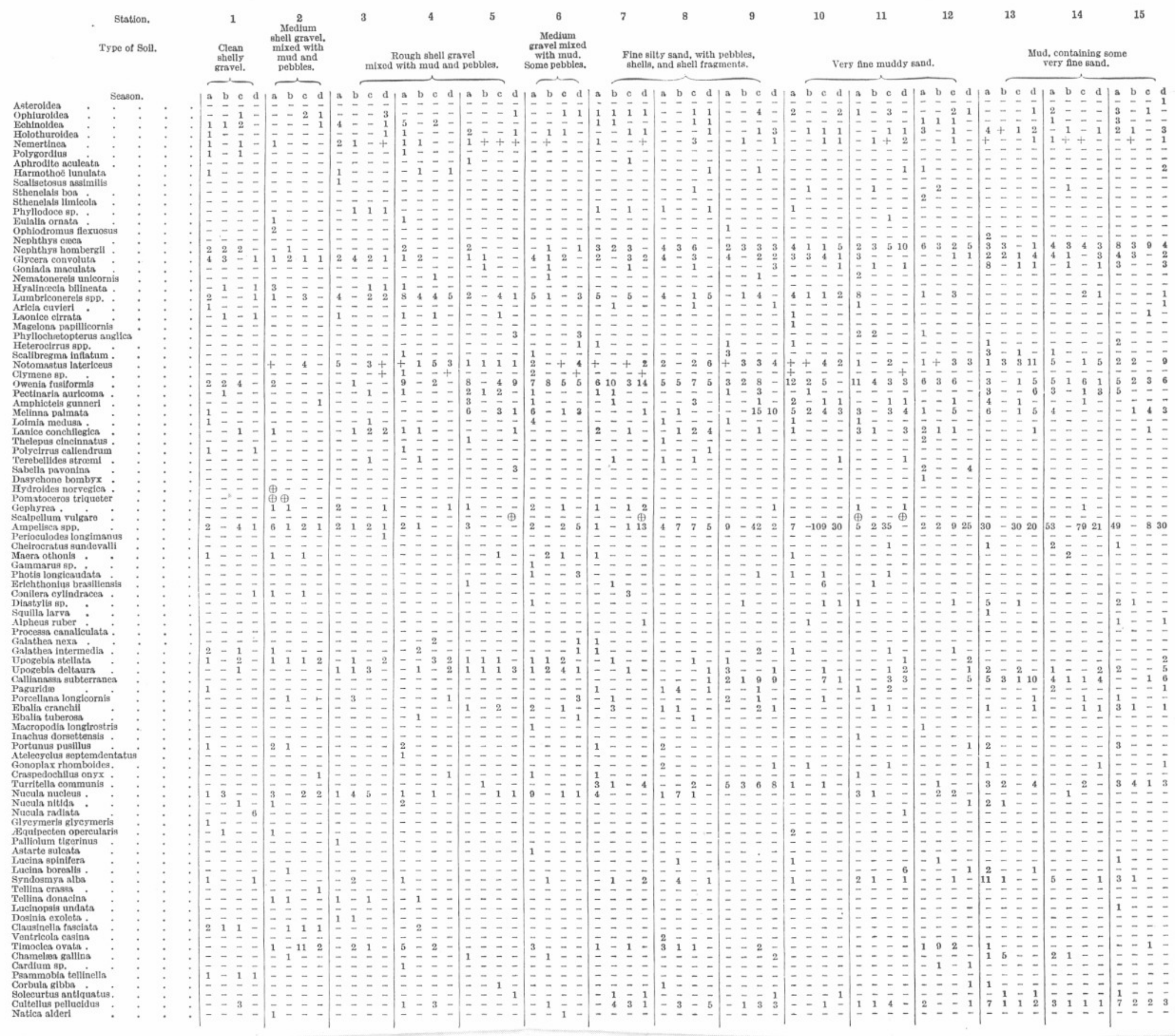


TABLE IV.

\section{Station.}

Directon Towed.

\section{Season.}

Hydractinin echinata Sertularella gayl
Hydrallmanta talcati Plumularis entharina Aloyonium digitatur Astropecten irrexularis Palmipes membranaceus Solnster papposus
Henricis a ankuinolent Btichastrella roses Asterias rubens ophiothrix fragilla Amphiura fillform Echinus esculentus Bpatangus purpureus
Echlnocardlum cordatum Phascollion atrombl Balanus sp. Scalpellum valgare Schizopoda . Pandelus montagul Hippolyte varians Spirontocaris cran
Ieander serratus Leander Berratus
Crankon vulgaris Philocheras sculptus Philocheras bisphinosis Galnthea nexa Galathea intermed Porcellann longicornis Eupagurus bernhardi
Eupagurus prideauxi Ananagurus lavis Portunus puber Portunus pusillus
Portunus holsatus
Portunus depurato Cancer nagurus Corystes cassivelaunus
Gonoplax rhomboides Gonoplnx rhomboil
Ebalis tuberosa Ebalis cranchii
Mais squinado Eurynome aspera
Hyus araneus Inachus dorsettensis
Macropodin longirostris Macronodila rostratns Phoxichillus spinosus.
Ovula patula (on Alcyonlu Ovula patula (on Alc
Natien alderi
Turritella comminuis Osecantus membrannceus Amphorina cervulen Antiopella hysalin Dendronotus frondosus
Pleurophyylldia lovent Archidoris tuberculat Jorunna johnstoni
Platydoris testudinaria leanthodorls pillosi Aamellidoris oblong : Ancula cristata Septa officinalis
Sepiols attantica Euryra arenosa
Ascldiella scnbra Amphiloxus lanceolatus

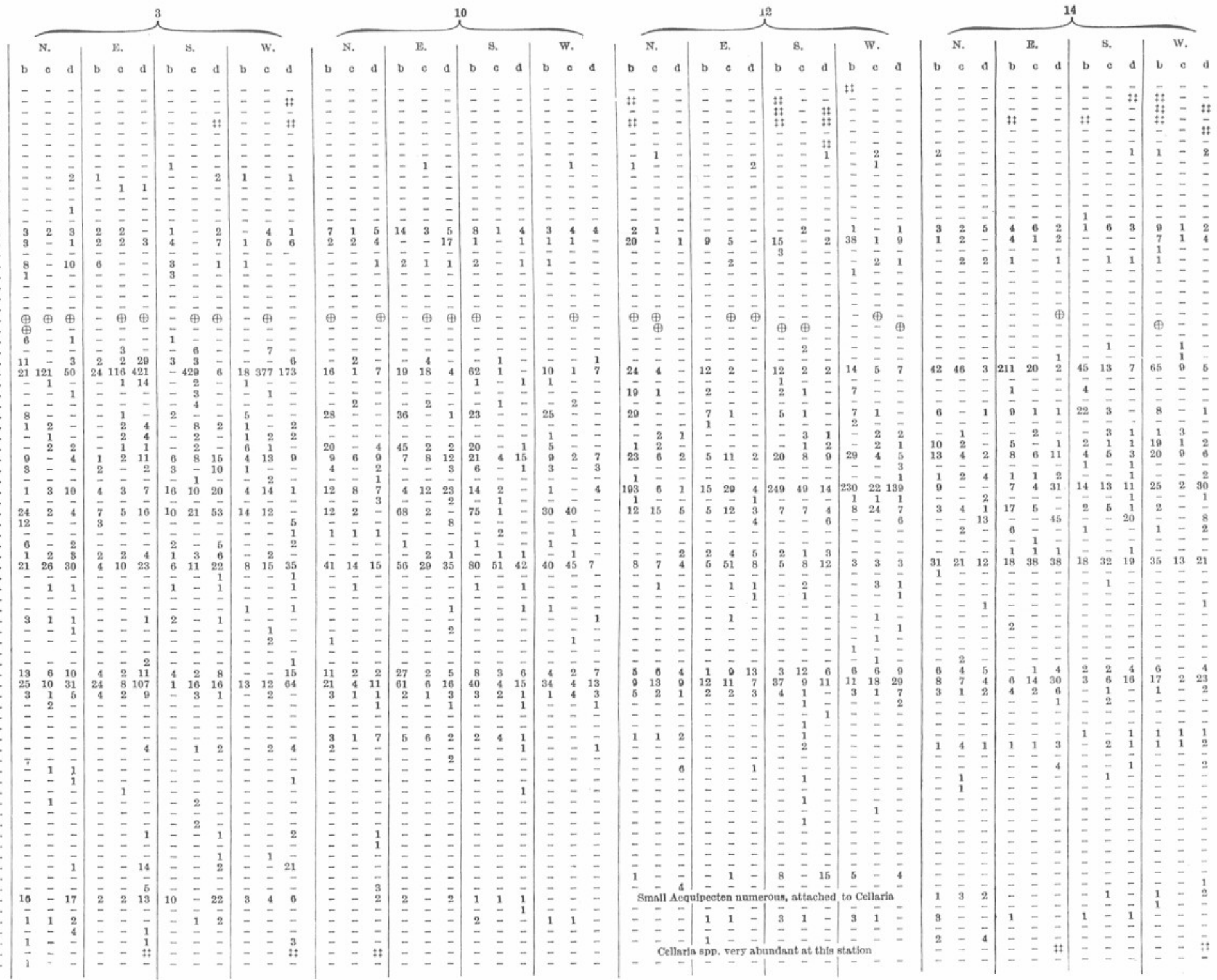


TABLE V.

\begin{tabular}{|c|c|c|c|c|c|c|c|c|c|c|c|c|c|c|c|c|c|c|c|c|c|c|c|c|c|c|c|c|c|c|}
\hline Name of Fish. & 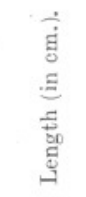 & 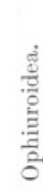 & 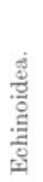 & 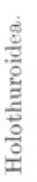 & 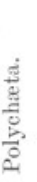 & 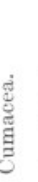 & $\exists$ & 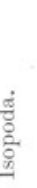 & 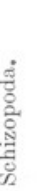 & 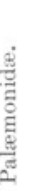 & : & 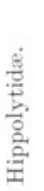 & 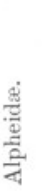 & 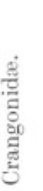 & 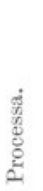 & 遏 & 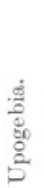 & 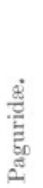 & 递 & 商 & 承 & 兽 & 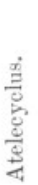 & 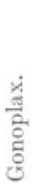 & 这 & 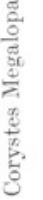 & 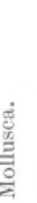 & : & 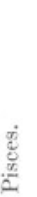 & 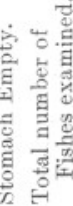 \\
\hline & $>5$ & - & $\overline{-}$ & - & - & - & $\frac{1}{2}$ & - & - & - & - & - & $\overline{-}$ & - & - & $\overline{1}$ & - & $\overline{-}$ & $\frac{2}{1}$ & - & - & - & - & - & - & - & - & - & - & $\begin{array}{ll}\overline{1} & 2 \\
1\end{array}$ \\
\hline \multirow[t]{4}{*}{ Trigla lineata } & $>10$ & $\overline{-}$ & z- & - & - & E & 1 & - & - & - & $\overline{-}$ & - & - & - & - & 1 & $\overline{-}$ & $\overline{-}$ & $\begin{array}{l}1 \\
2\end{array}$ & - & - & - & $\overline{-}$ & $\overline{-}$ & $\overline{-}$ & $\overline{-}$ & - & - & $\overline{-}$ & - \\
\hline & $>15$ & $\overline{-}$ & - & - & - & z & 1 & - & $\overrightarrow{1}$ & - & - & $\overline{-}$ & - & $\overline{1}$ & $\overline{-}$ & $\begin{array}{l}1 \\
2\end{array}$ & - & - & $\begin{array}{l}2 \\
1\end{array}$ & - & - & $\begin{array}{l}1 \\
1\end{array}$ & - & - & $\overline{1}$ & $\overline{1}$ & $=$ & - & - & \\
\hline & $>5$ & $\overline{-}$ & - & $\overline{-}$ & $\overline{-}$ & E & $\begin{array}{l}4 \\
3\end{array}$ & - & $\begin{array}{l}3 \\
1\end{array}$ & - & $\begin{array}{l}5 \\
4\end{array}$ & 2 & $\overline{-}$ & - & - & $\begin{array}{l}6 \\
5\end{array}$ & - & - & ${ }_{9}^{7}$ & $\overline{1}$ & - & $\overline{1}$ & - & - & $\overline{-}$ & - & $\overline{-}$ & - & - & $\begin{array}{ll}3 & 21 \\
- & 17\end{array}$ \\
\hline & $>10$ & - & - & - & - & 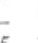 & & - & - & - & & 1 & & 11 & - & 6 & 1 & $\bar{T}$ & & - & - & 8 & 2 & - & - & & $\overline{1}$ & - & 2 & $5 \quad 28$ \\
\hline \multirow{3}{*}{ Trigla cuculus } & & $\overline{-}$ & $=$ & $\bar{z}$ & z & 5 & & - & - & - & $\overline{4}$ & $\overline{-}$ & $\overline{-}$ & 5 & - & $\begin{array}{l}4 \\
3\end{array}$ & $\overline{-}$ & 1 & $\begin{array}{r}16 \\
8\end{array}$ & 1 & - & $\overline{2}$ & - & $=$ & - & & 1 & $\overline{-}$ & & 12 \\
\hline & 15 & - & - & - & - & - & - & - & - & - & - & - & - & - & - & 4 & - & - & 1 & 2 & - & $=$ & - & - & - & & - & - & 1 & 1 \\
\hline & $>20$ & $\overline{-}$ & $\overline{-}$ & - & $z$ & E & $\begin{array}{l}5 \\
1\end{array}$ & - & $\overrightarrow{1}$ & - & $\begin{array}{l}0 \\
2\end{array}$ & $\overline{-}$ & $\overline{-}$ & 12 & 1 & $\begin{array}{l}3 \\
8\end{array}$ & $\overline{1}$ & $\overline{1}$ & $\begin{array}{l}1 \\
3\end{array}$ & - & $\overline{-}$ & 1 & - & $\frac{1}{-}$ & - & & $\overline{1}$ & $\overline{-}$ & & \\
\hline \multirow{3}{*}{ Trigla hirundo } & & - & - & - & - & - & 1 & - & - & - & 1 & 1 & - & 3 & - & - & - & - & - & - & - & - & - & - & - & - & - & - & - & \\
\hline & & $\bar{z}$ & = & - & $\begin{array}{l}z \\
\end{array}$ & - & $\begin{array}{l}1 \\
1\end{array}$ & - & - & - & $\frac{1}{2}$ & $\overline{-}$ & $\overline{-}$ & ${ }_{1}^{2}$ & - & 2 & $\overline{-}$ & $\overline{-}$ & 1 & $\overline{-}$ & - & $\overline{1}$ & $=$ & $\overline{-}$ & $\overline{-}$ & & $\overline{-}$ & $\overline{-}$ & - & 4 \\
\hline & $>20$ & - & - & - & - & - & 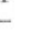 & - & - & - & 1 & - & - & 2 & - & 3 & - & - & 3 & 2 & - & 2 & - & - & - & - & - & & & - \\
\hline \multirow{5}{*}{ Trigla gurnardus } & $>5$ & - & - & - & - & 1 & 7 & $\vec{y}$ & - & $\underset{\gamma}{9}$ & 6 & 1 & - & 1 & - & - & - & - & - & - & - & - & - & - & - & - & - & - & & - \\
\hline & $>10$ & - & - & - & $=$ & 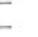 & 1 & 1 & 1 & - & 8 & $\overline{2}$ & $\overline{-}$ & $\frac{1}{17}$ & $\overline{-}$ & $\overline{9}$ & $\overline{-}$ & $\overline{-}$ & $\overline{-}$ & $\overline{-}$ & $\overline{-}$ & $\overline{-}$ & 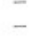 & - & $\overline{-}$ & & - & & 1 & 1 \\
\hline & $>10$ & - & - & - & - & - & 4 & 1 & - & - & 6 & 1 & - & 11 & - & 5 & - & 1 & 1 & - & - & - & - & - & - & 1 & - & & & 3 \\
\hline & $>15$ & - & $\overline{-}$ & - & $\overline{-}$ & - & $\begin{array}{l}3 \\
2 \\
2\end{array}$ & - & $\overline{-}$ & - & $\begin{array}{l}5 \\
9 \\
\end{array}$ & - & $\overline{-}$ & $\begin{array}{r}11 \\
8\end{array}$ & $\overline{1}$ & $\begin{array}{l}4 \\
6\end{array}$ & $\overline{-}$ & $\overline{-}$ & - & $\frac{2}{-}$ & - & $\overline{1}$ & - & $\overline{-}$ & $\overline{-}$ & $\overline{-}$ & $\overline{-}$ & $\bar{z}$ & & $\overline{1}$ \\
\hline & $>20$ & - & - & - & - & - & - & - & - & - & 5 & - & - & 2 & - & 1 & - & - & - & - & - & - & - & - & - & , & - & $\overline{-}$ & & 1 \\
\hline \multirow{8}{*}{$\begin{array}{l}\text { Lophius } \\
\text { piscatorius }\end{array}$} & & & & & & & & & & & & & & & & & & & & & & & & & & & & & & \\
\hline & $>20$ & - & $\overline{-}$ & $=$ & - & - & - & $=$ & $=$ & $\overline{-}$ & $\overline{-}$ & $\overline{-}$ & - & $\overline{-}$ & $\overline{-}$ & $\overline{-}$ & $\overline{-}$ & $\bar{z}$ & $\overline{-}$ & $\overline{-}$ & - & $\overline{-}$ & - & $\overline{-}$ & $\overline{-}$ & $\overline{-}$ & $\bar{z}$ & $\overline{-}$ & & $\begin{array}{l}3 \\
1 \\
1\end{array}$ \\
\hline & $>30$ & - & - & - & - & - & - & - & - & - & - & - & - & - & - & - & - & - & - & - & - & - & - & - & - & - & - & & & \\
\hline & & - & - & - & - & - & 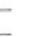 & - & - & & - & - & - & $\overline{-}$ & $=$ & - & - & - & $\overline{-}$ & $\overline{-}$ & - & - & - & - & - & E & $\overline{-}$ & & & $\frac{I}{6}$ \\
\hline & $>40$ & 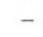 & - & - & - & - & - & - & - & & - & - & - & - & - & - & - & - & - & - & - & - & - & - & - & - & - & & & - \\
\hline & $>50$ & - & $\overline{-}$ & $\overline{-}$ & - & - & - & - & - & $\bar{z}$ & - & $\overline{-}$ & I & - & - & $\overline{-}$ & - & $\overline{-}$ & $\overline{-}$ & $\overline{-}$ & $\overline{-}$ & $\overline{-}$ & $\overline{-}$ & - & $\overline{-}$ & $\overline{-}$ & $\overline{-}$ & & & $\overline{1}$ \\
\hline & $>60$ & - & - & - & - & - & & - & - & - & - & - & - & - & - & - & - & - & - & - & - & - & - & - & - & - & - & & & \\
\hline & & & & & & & & & & & & & & & & & & & & & & & & & & & & & & \\
\hline
\end{tabular}




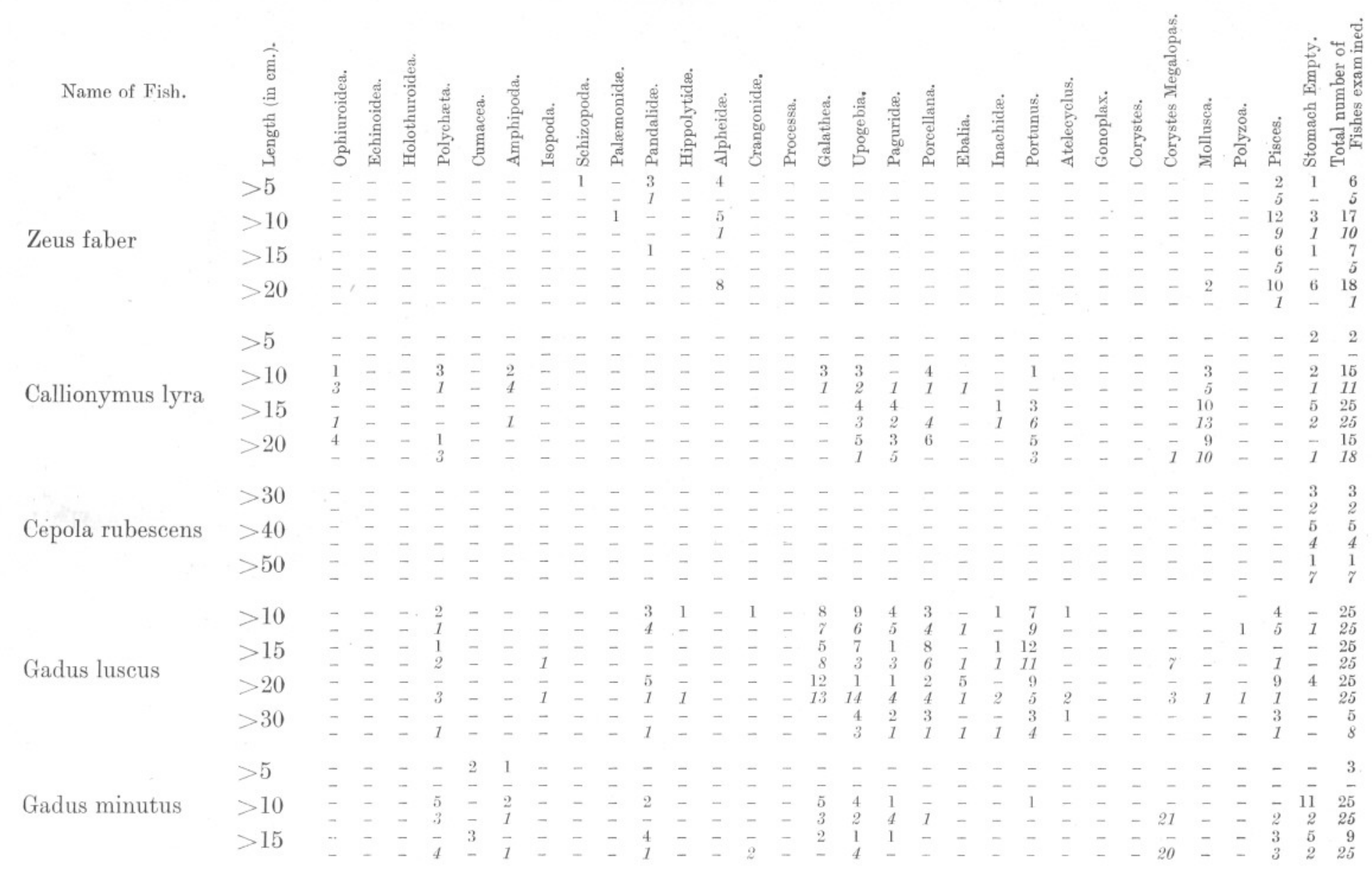




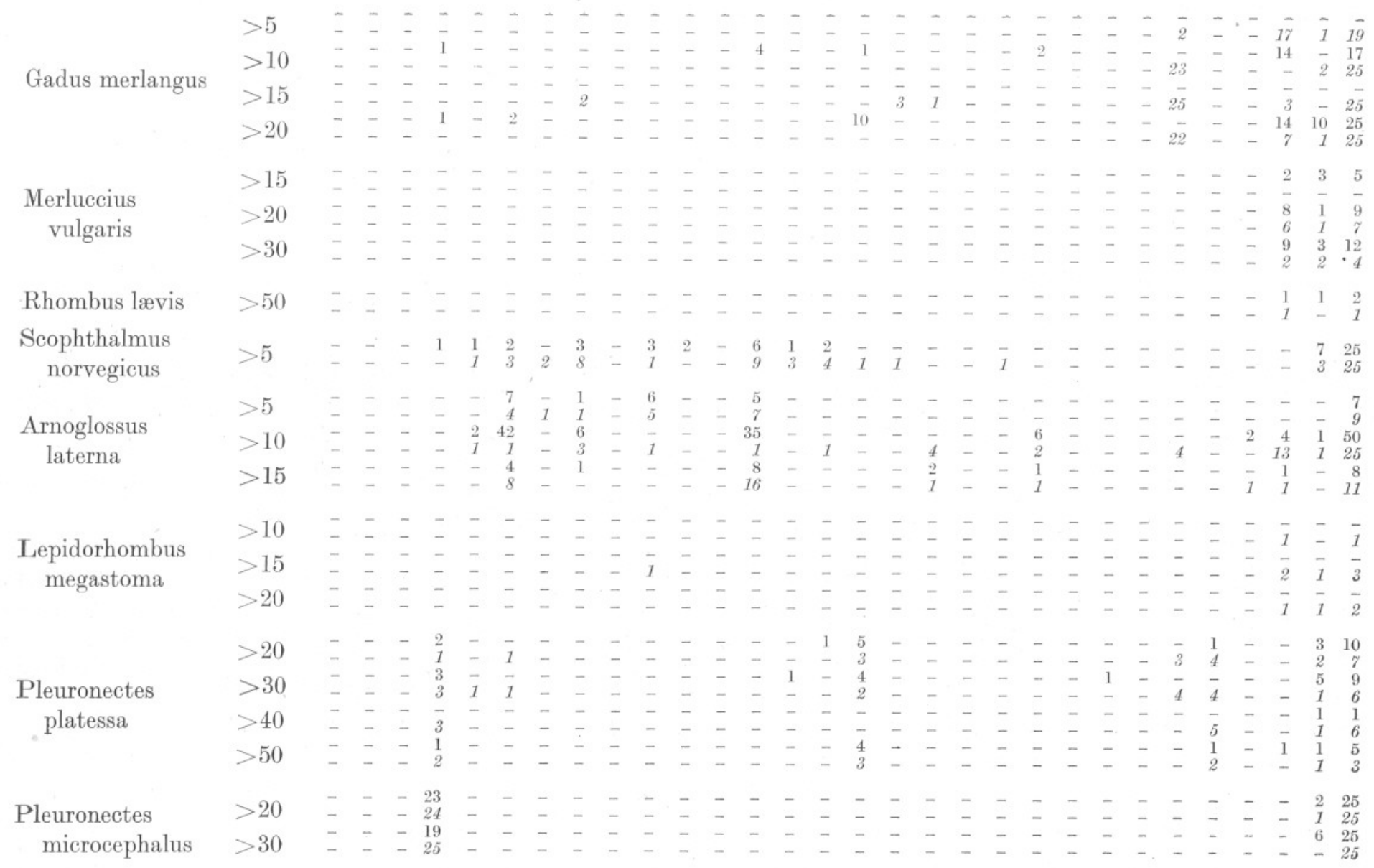




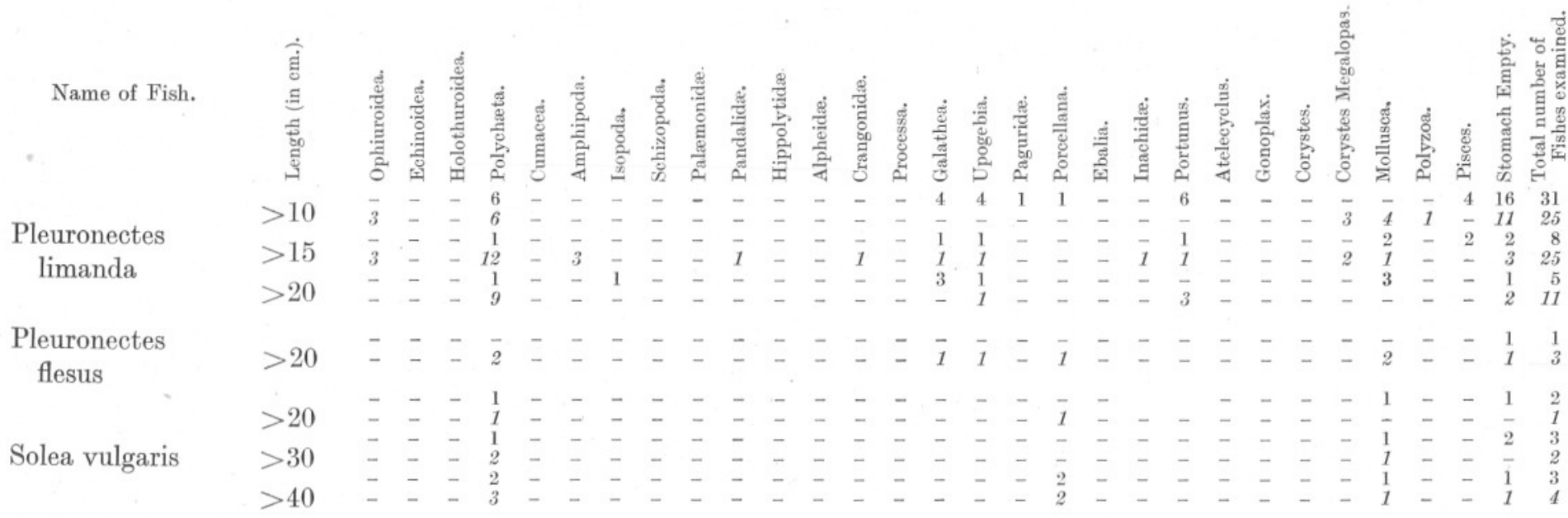

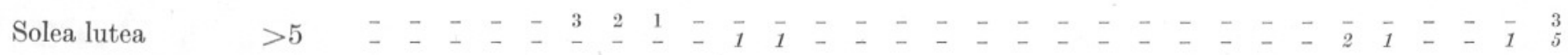

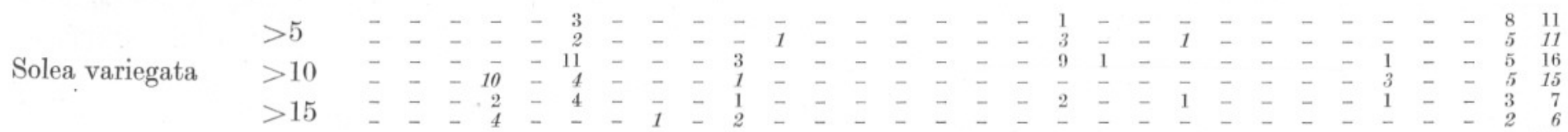

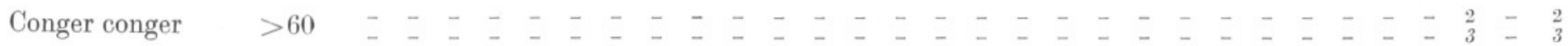

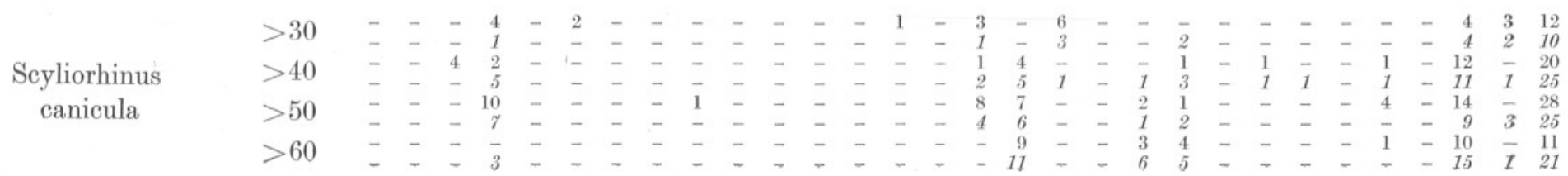




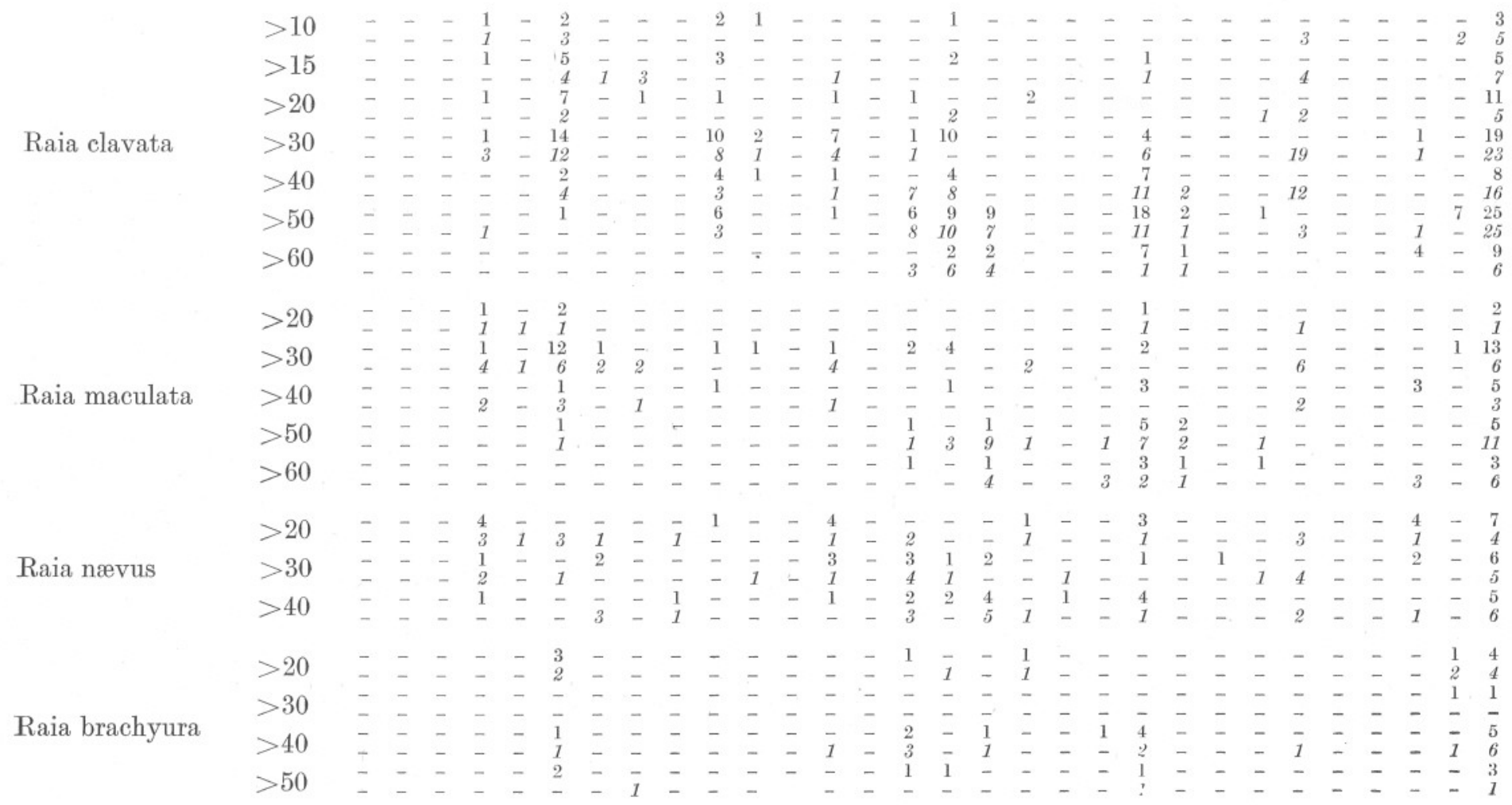

